\title{
Czech and Tartu-Moscow semiotics: The cultural semiotics of Vladimír Macura (1945-1999) In memoriam Vladimír Macura
}

\author{
Thomas G. Winner ${ }^{1}$ \\ 986 Memorial Drive, Apartment 404, Cambridge, \\ Massachusetts 02138 USA \\ e-mail: tgipwinner@mediaone.net
}

\begin{abstract}
Among the national scientific groups, it was the Prague Linguistic Circle that had the most decisive affinity to the work of the Moscow-Tartu school. This paper examines the work of one of the most tireless contemporary Czech interpreters of the Lotman school, Vladimir Macura (1945-1999), whose work on Czech literary and historical texts are outstanding examples of the reverberation of Lotmanian semiotics of culture in the Czech Republic. This is particularly the case in Macura's reevaluations of the texts of the Czech National Revival of the late eighteenth and early nineteenth centuries, especially in two books, Znamení zrodu (Signs of Birth) (1995) and Český sen (The Czech Dream) (1998). In these works Macura looked at this critical period in Czech national history as a multi-layered semiotic text in both the verbal and visual spheres. The present paper is an attempt at an exploration of Macura's treatment in this manner of the following: the Czech language, the city of Prague, the question of Czech national self-identification in general and as part of a larger category, the world of the Slavs. An important aspect of this project is an examination of Macura's exploration of the value functions of symbolic animals and plants in Czech Revival culture, and its relation to the
\end{abstract}

\footnotetext{
I am indebted to Pavel Janoušek, Director of the Institute for Czech Literature of the Academy of Sciences of the Czech Republic, for his great bibliographic assistance. I wish to express my gratitude to dr. Nadéžda Macurová for her kind permission to publish illustrations from Macura's works.
} 
axiology of Czech (Slavic) cultural identity. The paper is dedicated to Macura's memory.

\section{Introduction}

The Prague Linguistic Circle of the 1920s and 1930s and the TartuMoscow school of cultural semiotics are complexly interconnected. Both groups start from Saussurean linguistics and semiotics. However, the Prague group, and some of the later Russian "formalists," especially Jurij Tynjanov, and the Moscow-Tartu school broke with Saussure's rigid dichotomies (langue/parole, synchrony/diachrony, etc.). The first critique of Saussure was expressed in 1929 in a notable statement by Roman Jakobson and Jurij Tynjanov (1929) in which the authors asserted that each synchronic slice of a verbal text also has a strong diachronic character, for example in stylistic archaizing, and each diachronic system is not free of synchronic layers. Thus the static and the dynamic were now united. For Jakobson and Tynjanov, Saussure's bilateral sign was not sufficient; the significant unit was the text. But the literary text was also insufficient, and since, in the view of Jakobson and Tynjanov, such semiotic units need not be limited to verbal ones, the beginning of a semiotics of culture was laid. For particular signs were embedded in other signs of the text, and the boundaries of texts were permeable. As Mukařovský was to point out several years later (1936), external stimuli entered the text through the intention of the creating and observing subjects. Mukařovský saw the literary text in Hegelian terms as autonomous, subject to internal changes brought about by Hegel's Selbstbewegung (Czech samopohyb), but also vulnerable to outside stimuli. For Mukařovský the individual sign was infected by the context of other signs in the same text, and the text itself interacted with other literary texts cast in similar stylistic traditions (e.g. Romanticism), and national traditions as well (French literature). This position applied to all the arts. And toward the end of his life Mukařovský postulated a "System of Systems" which, while only sketchily defined, prophesied the Tartu-Moscow semiotics of culture and Lotman's semiosphere.

From the late 1920s to our days Euro-American semiotics has diverged, taking different paths: those who base themselves on Saussure's signifier and signified ${ }^{2}$ (primarily French and American semiot-

2 This led to such verbal concoctions as the concept of post-structuralism which reinvented semiotic contextuality. I have discussed this in Winner (1995: 243-275). 
ics $^{3}$ ) and those who broke through Saussurean boundedness, primarily the Prague and Tartu schools and the continuation of the Prague tradition by Jakobson during his American period (1942 until his death in 1982).

\section{The Prague Linguistic Circle and the Tartu-Moscow school}

The Prague Linguistic Circle and the Moscow-Tartu school chronologically overlapped. In 1973 in Moscow, during our first face-to-face meeting Jurij Lotman told me that he was in correspondence with Mukařovský, and that he was concerned about the harsh political climate under which Mukařovský had to live and work at that time.

While in the 1920s Mukařovský, the chief aesthetician of the Prague group, was still drawn to the Russian Formalists, by the early 1930s he had repudiated the principles of their project in his sharply critical review (1934) of the Czech translation of Viktor Šklovskij's most radical formalist statement, his programmatic Theory of Prose (O teorii prozy).

It is thus important to see the pivotal differences between, on the one hand, French and American "structuralism," firmly placed into the Saussurean mold, and the program of the Prague group whose agenda was launched in renunciation of Saussurean statism and advanced instead the notion of system or structure as relational and dynamic, forever in motion and implying multifunctionality and polysemy, thereby launching Prague structuralism and later semiotics as an original initiative which led to the path-breaking sign theory in various domains, not only verbal, but also visual, audial, gustatory and tactile texts, and to the first study in semiotics of culture, without naming it as such, Bogatyrev's investigation of the function of folk costumes in Moravian Slovakia (Bogatyrev 1936), and was later to lead to the broad Lotmanian program of semiotics of culture and, towards the end of his life, to his formulation of the principle of the semiosphere (Lotman

\footnotetext{
3 Peirce was not a perceptible influence on either French or Prague-Tartu-Moscow semiotics until relatively recently, except for the work of Jakobson during the 70s and 80 s and the pioneering work of semioticians like the late Max Fisch and his group, Kenneth Kettner, the late Richard Martin in the United States, Gérard Deledalle in France, Elizabeth Walter and the late Max Bense in Germany, and Jerzy Pelc and his school of logical semiotics in Poland. It is therefore not part of our consideration in this paper.
} 
1990). The Prague school thus foreshadowed Tartu semiotics of culture in their rejection of the Saussurean dichotomies, their teleological model, their view of literature not as an isolated series but as related to other artistic and broadly cultural domains, including everyday behavior and history, thus abandoning Saussure's logocentrism. Whereas the Tartu-Moscow school initially posited natural language as the primary modeling system, and all so-called secondary modeling systems as structured along the model of this primary system, by the 1980s this school had cast off this split into the two classes of modeling systems and emancipated non-verbal semiotic systems from the hegemony of the linguistic model as the primary modeling system, as had the Prague group earlier.

\section{Vladimír Macura (1945-1999) and the Tartu-Moscow school}

I turn now to one of the most persistent interpreters of the relation of the Prague school and the Moscow-Tartu school who, unfortunately died at a very young age this past April, whose works were of signal importance and uniquely original, but who, because of his premature death is not known to any extent outside the Czech-speaking world.

I am thinking of Vladimír Macura (1945-1999) to whose memory this paper is dedicated (Fig. 1). He was an admirer of Lotman and his school and examined literary and historical texts in the manner of Tartu semiotics of culture, and he also had a significant interest in Estonian language and culture in which he found many parallels to the evolution of Czech culture and language. He was struck by the fact that both the Czech and the Estonian nations, both small in size, found themselves, in the nineteenth century, overwhelmingly dominated, politically, culturally, and linguistically, by other cultures, German in the case of the Czechs, Russians and Germans in the case of Estonia. Macura learned Estonian, and translated some works of Estonian literature into Czech, and some of his works were also translated into Estonian. Only a few examples of his work with or on Estonian topics must suffice here ${ }^{4}$ They are "Legendaarne Kangelanna" (Horisont, Tallinn) (Macura 1998 (an Estonian interpretation of the Czech Libuše myth); "Kümme XX sajandi tšehhi luuletajat" [Twenty Czech Poets of

\footnotetext{
4 For a full list of Macura's work that is concerned with Estonian culture, see References below.
} 
the 20th Century) (as editor), Eesti Raamat, Tallinn (Macura 1996); "Eesti keel ja kirjasõna tšehhi ajakirjas aastal 1946", Keel ja Kirjandus (Macura 1974). He also became interested in Czech-Estonian literary relations (1976) and introduced several Estonian writers to Czech readers (A. Tammsaare (1976), D. Vaarandi, E. Niit, V. Luik (1988), Lennart Meri (1991)). He interviewed Lotman and published this dialogue both in Czech and in Slovak (1991, 1992), and his many studies on the Moscow-Tartu school (1994, 1995a, 1995b) are of great interest.

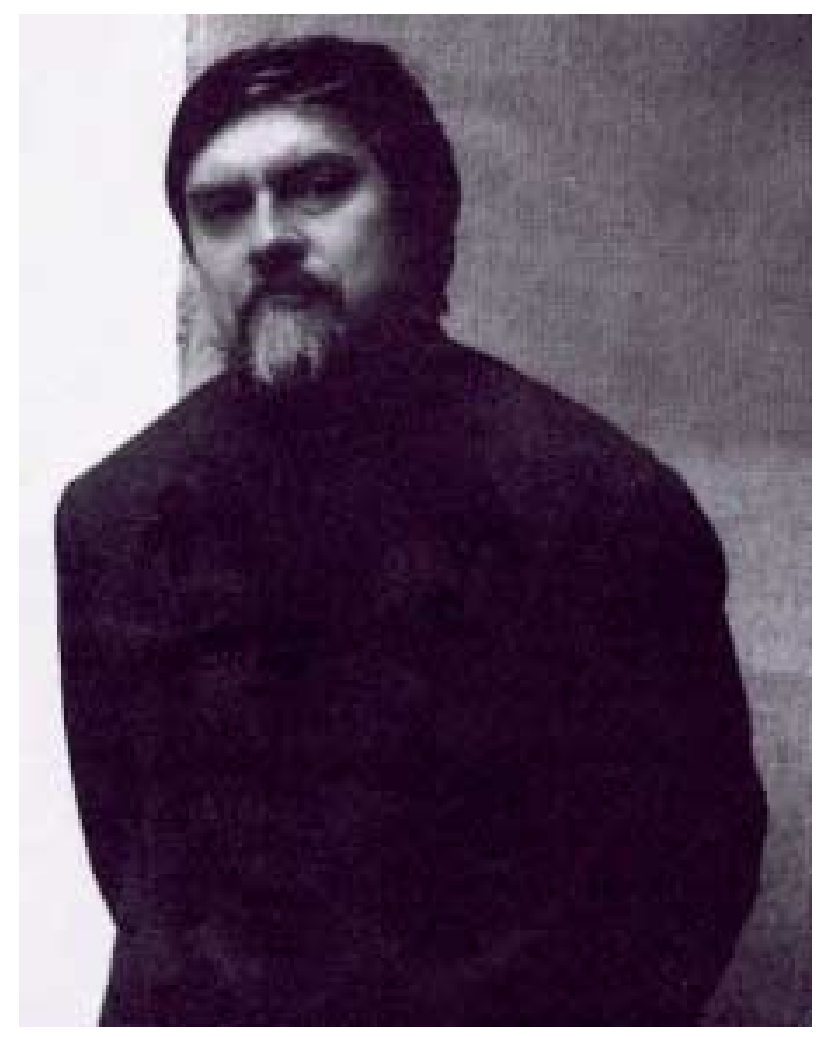

Figure 1. Vladimír Macura 1945-1999.

In 1974 Macura co-founded (with V. Novotný) the then illegal Society of Friends of the Baltic (Baltický svaz), illegal in communist Czechoslovakia which published a samizdat journal called Läänemere Liidu 
Liige. After the "velvet revolution," the journal became official under the new name of Buletín česko-estonského klubu Baltica. When writing about Estonia during the communist reign, Macura frequently used the nom de plume Vladimír Kreutzwald, after the name of the Estonian Revivalist, F. R. Kreutzwald (1803-1882) who recorded Estonian folklore and produced the epic Kalevipoeg, the story of the mythical founder of the Estonian nation.

\section{Macura's original work on semiotics of culture}

Macura's writings covered many genres: novels, scholarly essays on literary theory, book reviews, journalistic feature articles, and translations, mainly from Estonian to Czech. His studies at Charles University in Prague in the tradition of the Prague Linguistic Circle (he was a student of Felix Vodička), shaped his structuralist and semiotic approach in the analysis of literary and historical texts. In the 1980s, when Moscow-Tartu writings became more freely available, he was strongly attracted to Lotmanian semiotics of culture, which is evidenced in his historical writings on the Czech National Revival (Národní obrození) of the late eighteenth and early nineteenth centuries. This new perspective characterized his book, Signs of Birth (Znamení zrodu, 1995) and his last published monograph Český sen [The Czech Dream] (1998). In Signs of Birth he saw the critical period of the Czech National Revival as a multi-layered semiotic web, characterized by a certain artificiality, mystification and game-playing on the part of the Czech intelligentsia. This was a radical departure from the traditional Czech view of the popular romantic Herderian nationhood. Macura's whimsically entitled Masaryk's Boots and othersemi(o)feuilletons [Masarykovy boty a jiné semi(o)fejetony] (1993), incorporates selections from his feature articles that appeared in the weekly Tvar (Form) during 1992-1993. Themes of Czech history and disquisitions on the Czech language and Czech literature are interspersed with semiotically interpreted popular pieces, on advertising, Czech banknotes after the "divorce" from Slovakia, the Czech flag, Romas as "others," the history of Czech toponymies, and on other themes. In The Czech Dream (Český sen, 1998), the last book before Macura's death Macura focuses on the image of the Revival as an awakening (probuzeni) from sleep or from a dream, which suggests the Lotmanian semiosphere, as I will note. 


\section{Macura's semiotics of the Czech National Revival}

What was the historical background for these treatments of the Czech National Revival? I digress to discuss this very important question.

As a result of their defeat in 1621 by the Imperial forces in the Battle of the White Mountain [Bílá hora], the Czechs were deprived for a long period not only of their political independence, but also of much of their cultural and artistic life since after the Czechs were vanquished in 1621, all aspects of Czech culture were threatened or nearly obliterated. The Protestants were persecuted and expelled from the country, the Czech aristocracy was decimated; Czech books were burned. German and Latin replaced Czech in many cultural spheres especially in the eighteenth century, leading to the virtual obliteration of Czech as a written language. During this period, especially during the reigns of Maria Theresa (1740-1780) and of her son Joseph II (1780-1790), the Austrian empire followed a policy of intense centralization and Germanization. Joseph's educational reforms essentially Germanized all levels of the school system, including elementary schools in the Bohemian and Moravian crown lands, down to the level of village elementary schools. Czech books were no longer printed.

Nevertheless, the baroque, as a quintessentially counter-reformational artistic movement, blossomed following the Czech defeat. Magnifcent architectural objects and a superb lyric tradition persisted; but by the eighteenth century Czech literature could no longer remain unaffected by the intense Germanization efforts by the Viennese court. Thus, during the late eighteenth and early nineteenth century, a Czech National Renewal (národní obrození) took shape, rejecting the cultural imperialism of Vienna. The Czech language, long dormant, was recodified and became again the basis of a literary tradition. Some exquisite romantic poetry by Karel Hynek Mácha, was an exception to the predominantly politicized writing, directed toward the cause of the National Revival of ethnic and linguistic identity.

Thus by the late eighteenth and early nineteenth century the Czechs regained their written language. No longer was Czech rejected, even by some Czech intellectuals, as an insignificant language reduced the unwritten vernacular of the peasants and the urban proletariat, while the elite wrote in Latin and German and often spoke only German. Two types of Czech had survived during the eighteenth cen- 
tury: the archaic and conservative language of the courts, and a popular oral type, spoken primarily by the peasants and urban proletariat (cf. Havránek 1936: 80). During the National Revival during the late eighteenth and early nineteenth century, Czech was recodified first by Josef Dobrovský (1753-1829), and later again by Josef Jungmann (1773-1847). It was illustrative for the unfortunate state of Czech of that time that Dobrovský's fundamental Czech grammar was written not in Czech but in German (Lehrgebäude der böhmischen Sprache) (Dobrovský 1909), and that many of the language reformers themselves had only a minimal academic knowledge of the Czech language gleaned from the pages of the pre-1621 literature (cf. Havránek 1936:84). Later, however, Jungmann's works on the Czech language, Slovesnost [Literature] (Jungmann 1829), Historie literatury české [History of Czech Literature] (Jungmann 1825), and his monumental Slovnik česko-německý [Czech-German Dictionary] (Jungmann 1835-1839), were written in Czech.

Macura saw the Czech Revival as a self-conscious process, as an intentional pedagogical design on the part of certain intellectuals, among them Josef Dobrovský and Josef Jungmann as a complexly structured sign system (cf. Janoušek 1999: 334) which led him to the notion of Revivalist culture as a game, appropriating Lotman's differentiation of "play" and "art." In play the situation is conventionally treated "as though" it were real, assuming the player "lives" in the game and follows its unconscious rules. In such a case a stuffed tiger is accepted as "pretend-true", inspiring "pretend-fear," whereas a work of art makes no such pretensions. Accordingly, Macura holds (1995: 102-103) that the National Revival was looked upon as an ideal, embodying the human ability to create something higher than reality, namely a design for striving toward the divine. But at the same time, there existed a profound pessimism, casting doubt on the human ability to achieve so lofty a goal. Could the gap between the small group of intellectual "Awakeners," and the unlettered masses be closed? For the Czech language no longer existed as a general means of communication, and thus it must have appeared to the small group of recodifiers of the Czech language that they were creating a gamelike reality. As the poet Jan Kollár (1793-1852) facetiously wrote, "We play on a piano that perhaps does not have any strings" (Kollár 1952: 351 in Macura 1995: 105). Thus the contrast between play and life in Czech Revivalist culture, often seen by contemporaries as ironic and playful, or at best as naively optimistic. 


\subsection{Other semiotic systems of the National Revival}

\section{Linguocentrism}

The central issue became the recodification of the Czech language and the propagation for its use in daily life in an urban population, including the intellectuals. And this led to such epithets as Czech as a philological nation (abecedářský národ [Šafařík]). Especially in the first half of the nineteenth century linguistic questions transcend the boundaries of linguistics and become reflections of a specific cultural and social perspective. For example, the complex Czech case system was not only seen as a morphological trait of the language, but, it took on axiological dimensions of such positive values connected to the language as musicality and harmony, in contrast to the less valued non-inflectional or partinflectional, languages. The latter were metaphorized as a wall constructed so that the nails (the prepositions that act like case endings) are openly visible, whereas in Czech and other inflected languages, as most other Slavic ones, the nails are hidden, making for greater elegance (Macura 1995: 43). Nor was orthography seen as an arbitrary system of rendering the sounds of a language. It also became an autonomous value fused to aesthetic and political phenomena. For example, after Russia's victory over Napoleon in 1912 there were various calls on the part of the, Awakeners to adopt the Cyrillic alphabet (Jungman 1948: 155). Thus the Czech National Revival, and even much of modern Czech culture, took on a strongly metalinguistic character, and this linguocentrism is still active today, and comes strongly to the fore in the language games of the interwar Czech literary avantgarde.

\section{The city - Prague}

As in other European cultures, the axiology of the city begins to change during the nineteenth century. As is seen in the works of Dickens, Sue, and Balzac, the city, which until the end of the eighteenth century was valued negatively by the pre-Romantic writers who idealized the countryside, began to be valued positively, as it was by Karel Hynék Mácha, the Czech Romantic poet par excellence. Mácha now praised the city's picturesque charm. Thus Mácha writes "towns like small white markers peeked out of the dark shadows; and light smoke 
curled up from them" ["města, co bílá znamínka vyhlížela z šerých stínů; nad ními se kroužil lehký kouř”'] (Mácha 1961, II.210 in Macura 1995: 178). Yet the situation was different from that in other European countries, for the image of Prague enters the literature of the Revival often by the back door, by way of the little valued peripheral genres of art, the urban dramatic farce, especially Czech adaptations and/or translations of Viennese humorous folk plays. In Macura's example, the Czech play Alina or Prague in another Part of the World [Alina aneb Praha v jiném dílu světa] by Štěpánek, was simply a free translation of the Viennese folk play by Karl Ruber, Aline, oder Wien in einem anderen Weltteil. Viennese localized details are simply transposed to Prague equivalents (street names, landmarks, etc.).

Macura sees Prague as having a dual sign function in this period: it is depicted both in its realities, its streets, houses and inhabitants, and as an allegory. The former function is realized on what Jakobson called the axis of combination (syntagmatic axis), indexically. In the allegorical aspect, on the other hand, elements are based on similarity, iconically (Macura 1995: 180). Allegorically Prague is personified as a female, as its Czech name, Praha, is grammatically feminine. Prague then is metaphorized as "Mother" (during the Interwar first Czechoslovak Republic, the motto "Praha matka měst' [Prague, Mother of Cities] was painted on the red-yellow streetcars of the city. The figure of Prague as "mother," "bride," "widow" (of kings) brings it near to the Revival theme of vlast (one's home country, equivalent to the Russian rodina and the French patrie. Again, like its French and Russian equivalents, but unlike the German Vaterland (grammatically neuter, vlast is grammatically feminine, and is axiologically tied to the symbolism of the Czechs as a family of father, mother, and children (Macura 1995: 181)). (Fig. 2-3).

In Lotman's terms, boundaries become signs; Prague is split into two parts, an "old" and a "new", where "old" is identified with the allegorical (iconic) past expressed in such attributes as "old," "venerable" (staroslavná), and "brave" (chrabrá), whereas "new" is represented by the contemporary realities of the city, its physical shape, its streets, real people, etc. In Czech mythology the allegorical aspect of the city is a meeting of this world and the divine world (Macura 1995: 183), suggesting the traditional folk image of the cosmological tree, the "tree of life". Here Macura comes very close to the Lotmanian function of myth as a device for creating a picture of the world, and to 


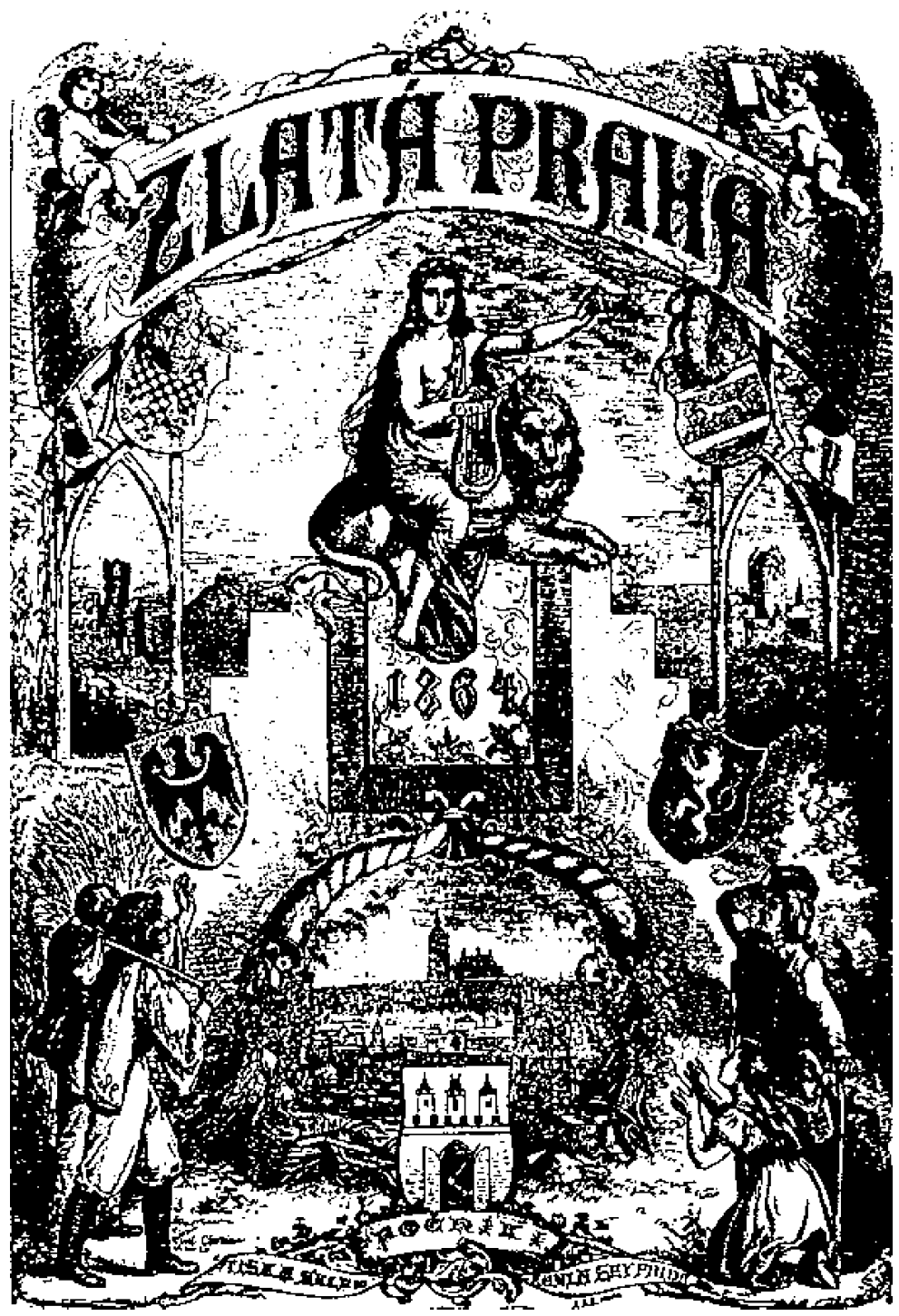

Figure 2. National symbols which had become established in the culture of the National Revival, had become accepted as natura andl traditional in the second half of the nineteenth century. Tracesof Revival culture are seen in the stylization of Pragueas a sacred space, the Macca of Czechdom, etc. Illustration from the cover of the annual Zlatá Praha (Golden Prague) (1864). 


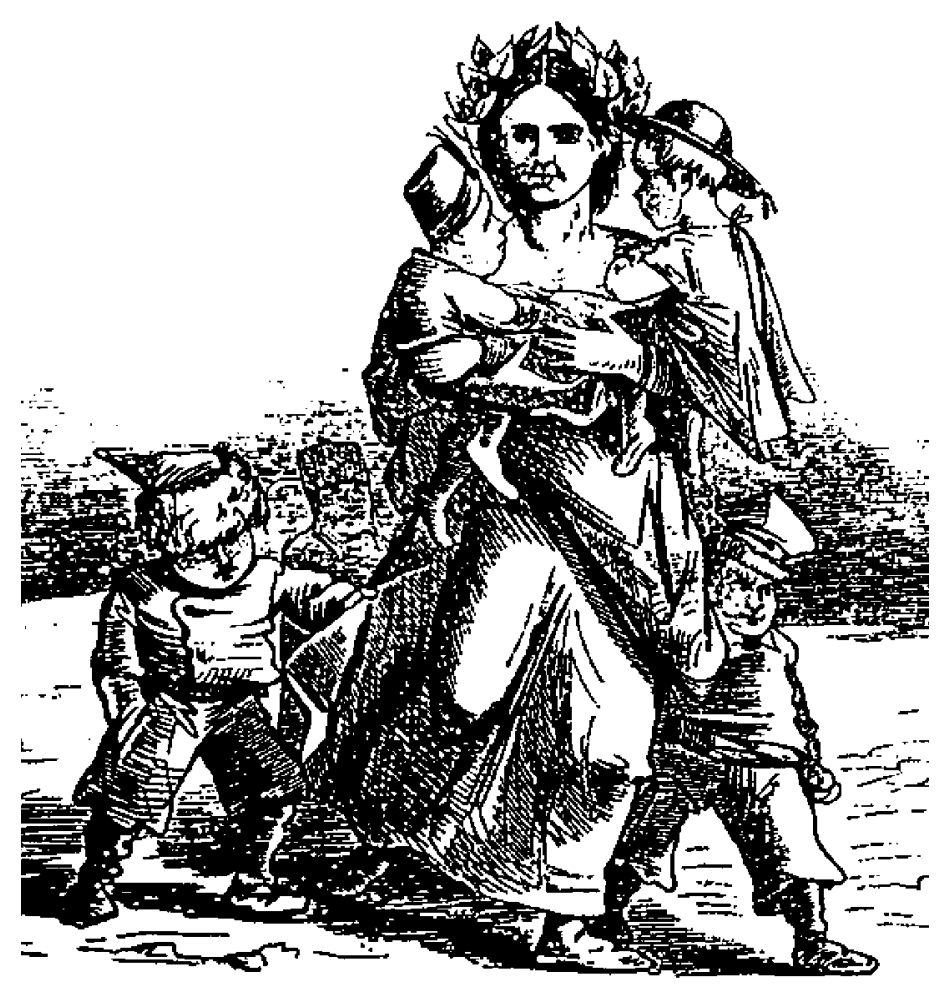

Figure 3. Mother Slavia with her children. Image of the Panslavic "family". (Humoristické listy [Humor Magazine] vol. 5. 1863, p. 328).

establish an identity to distant spheres (Lotman 1990: 152). The tree of life, frequently supplanted by the image of the mountain represents the link between humans and the gods. In Bakhtin's sense, its axiology is spatial-vertical, it moves from the bottom of the mountain, the actual reality, the bowels of the earth, man, and even lower the devil(s), upwards to the mountain summit which reaches to the ideal, the godhead. The mountain summit and Prague both are bipolar mythemes, interchangeable images and their iconographies share the metaphoricity of "cathedral," "castle," "crown," "throne," etc. (Macura 1995: 185). Similarly, the Slovak emblem are the Tatra mountains. Indeed, a specific tree, the linden tree (lípa) became the Czech (or Slavic) mythical tree par excellence. (Fig. 4-5). 


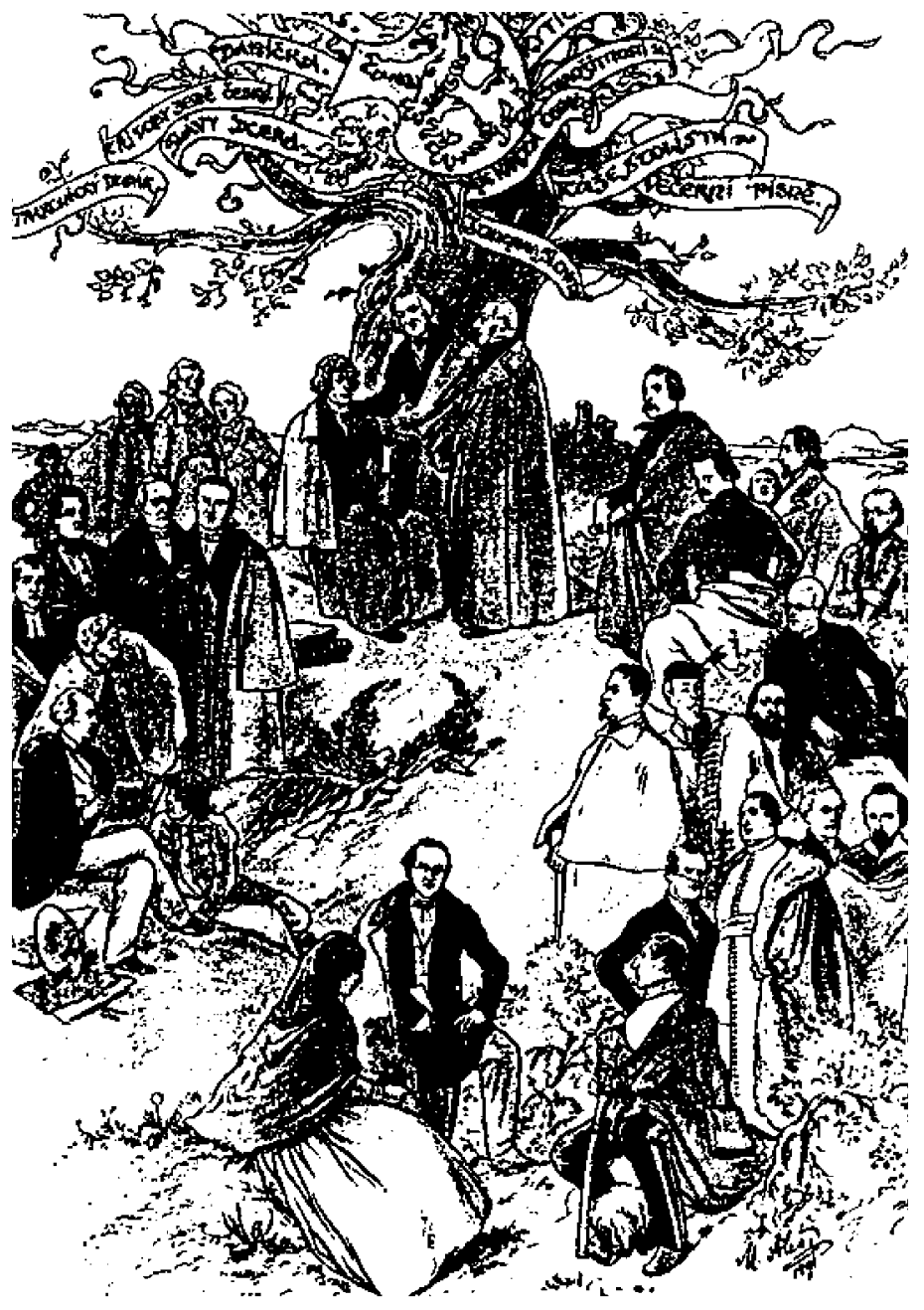

Figure 4. The symbol of the "Slavic linden tree" arose in the first quarter of the $19^{\text {th }}$ century as the opposite of the German oak. The female linden tree (the Szech lipa is grammatically feminine) with its soft wood, a source of honey, was opposed to the (German) oak and exploited as as central emblematic item: Slavic honey vs. bitter German acorns, Slavic busy bees vs. German parasitical drones, Slavic softness and benevolence vs. German severity and harshness, a.s.o. The illustration is by the Czech painter Mikoláš Aleš. It shows Czech cultural and political figures as the roots, and titles of Czech songs and poems as the branches of the linden. 


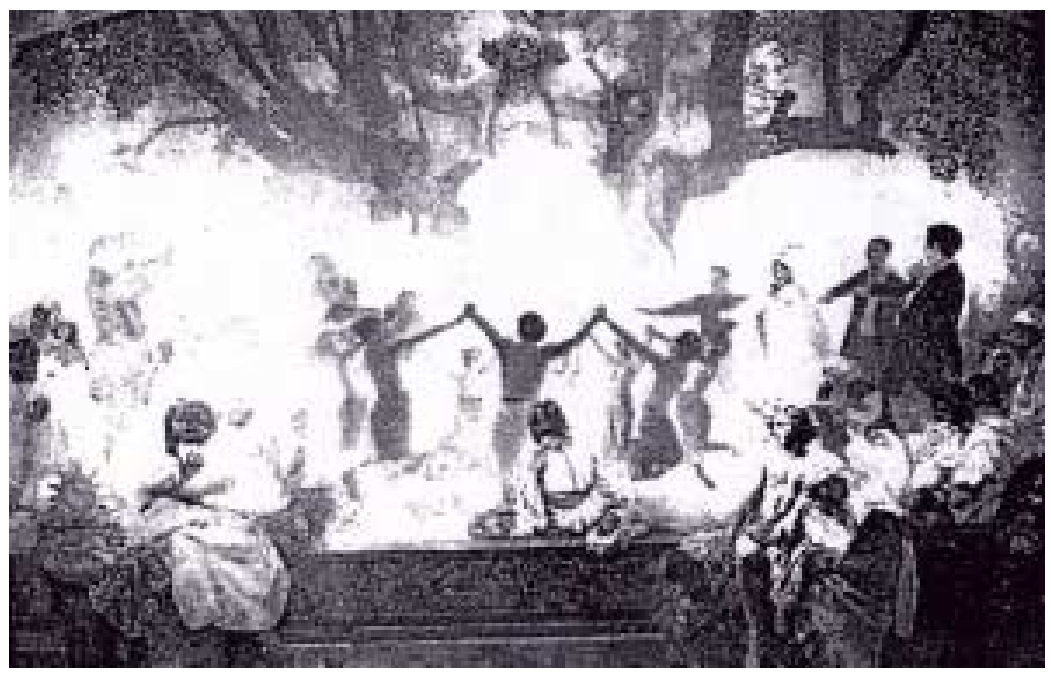

Figure 5. Alfons Mucha "Youth Under the Linden Tree" (1926).

\section{The Czech nation (národ, vlast)}

The problem of nationhood permeated the National Revival. What is a nation, and how it can be defined as something specific, was, after all, an important theme of he Romantic nationalism pervading Europe. But while it was no problem to define what characterized the German or the French nation by territory and distinctive language, the definition of what constituted Czech nationhood was far more complex. For the Czech nation could not easily be defined by language. Macura cites an anecdote involving the Czech writer Jan Neruda (1834-1889). In a Czech small town Neruda initiated a conversation with a woman innkeeper concerning a recent $\mathrm{Czech}$ national celebration that had taken place in this town. "Yes, the Czechs had a celebration here," agreed the innkeeper in perfect Czech. "But there live only Czechs here," was Neruda's reply; "and aren't you a Czech yourself?" "I," replied the innkeeper, "I am neutral". (Neruda 1961: 375-376 cited in Macura 1998: 54). To what nationality did this lady feel she belonged, asks Macura. Was it Austrian, as a subject of the Habsburg monarchy? Or did she feel that she belonged to the Kingdom of Bohemia, But the epithet Bohemus or Bohemicus did not necessarily identify a language, and could simply mean a subject of the Kingdom of Bohemia which 
was part of the Habsburg empire. And this subject, especially in the cities, might more probably speak German than Czech. A Czech could also be called a German, even a Czech speaking peasant, as a subject of the Holy Roman Empire. Similarly, the German label Böhme could be applied to both German and Czech speakers. But "Czech" could also be seen as part of a larger unit, the world of the Slavs (Slovanstvi). The association of Czech with Slav led to attempts at creating a universal Slavic language (e.g. Jan Herkel's Elementa universalis linguae slavicae (1826), and Kollár's notion of Slavic Solidarity (Slovanská vzájemnost) (Macura 1995: 157).

\section{Smallness: the new ideal of nationhood}

The view of Czechs as part of a larger unit, Slavdom, was weakened by the appearance of an article by the Czech historian Erazim Vocel (1864). It appeared in the Journal of the Czech Museum (Ćasopis Českého Muzea in its 20th volume, entitled "The Estonian Learned Society in Derpt" (Učená společnost estonská v Derptu") (Derpt is today's Tartu). The article was a paraphrase of some texts in the Estonian Learned Society's Verhandlungen der gelehrten estnischen Gesellschaft. Two points strike us. The first is that the language of the Verhandlungen is not Estonian but German, thus a situation analogous to that in the Czech lands through the early period of the National Awakening. The second interesting matter is Vocel's choice of texts in the Estonian journal for paraphrasing, namely two historical essays in German by D. H. Jürgensen one on the Estonian language and the second one on Estonian literature, "Über die Entstehung der beiden Hauptdialekte der estnischen Sprache" and "Kurze Geschichte der estnischen Literatur" (1846: I: 19-25; I I: 41-52; I I I: 61-73). It is clear why Vocel chose just these two texts and added to them two translations from the German translation of two Estonian folk texts, ("Wannemunna's Sang" and "Koit and Hämarik") while omitting other learned articles on historical topics and other fields. This choice was clearly engendered by the interest in the late Czech National Revival of questions of the nature of national languages and the related fields of literature and oral art. Vocel knew German but not Estonian, nor could he have had any knowledge of Estonian literature and folklore, but he enthusiastically foretold a great future for the reawakening of Estonian culture, in which he saw a promising analogy to the Czech situation. 
Hence an enthusiasm for the culture of a nation, even smaller than the Czechs, took precedence over the desire of Czech intellectuals to identify with a larger body of related cultures, all of Slavdom, that had dominated Czech Revivalist thought in the early decades of the nineteenth century. It was not only Estonian culture that fascinated the Czechs now, but they began to identify with other smaller nations rebelling against foreign dominance, namely the Irish, the Basques, the Flemish, and the Greeks. This new self-identification of the Czechs with other small nations expressed changed values in which the powerful attributes of largeness were gradually displaced by those of the spirituality, modesty, simplicity of the cultures of small ethnic groups (Macura 1995: 166). The positive value of the concept of the "Middle" (stred) evolved with the process of the creation of a Czech philosophy, akin to Herder's concept of the golden middle ("die goldene Mitte"). For the Czech historian František Palacký the Czech nation mediated between and bridged East and West (Palacký 1848). Such notions continue to characterize the Czech nation as moderate and eschewing the radical extremes which still has significance today.

5. The mythological function of nature: animals and plants

Macura semioticized properties of the Czech Revival culture such as the axiological function of flowers, plants, trees, and animals (Macura 1995: 20-30). The medieval flower symbolism was transformed in the nineteenth century language of sentiment and love of the Biedermeier period, similar to other European cultures. Just one example must suffice here: the oriental flower symbolism of the rose as a symbol of perfection and love was taken over by Christian medieval iconography as the sign of the Holy Grail, the heart of the Virgin Mary and, in general, as a metaphor for the Holy Virgin. This metaphor and other oriental flower metaphors became secularized and eroticized in the Czech literature of the National Revival (the rose as a metaphor for love and the lily as a sign for innocence). The Czech identification of the red of the rose and the white of the lily with Red and White combination of the Czech national colors (Macura 1995: 22) become a strong extended metaphor for Czechness. Furthermore, in the National Revival two animal and plant species conveyed the idea of Slavdom and of Czech identity, namely the dove (holub) and the linden tree (lipa). For the Czech Revival the dove was a Slavic symbol, and the abundance of pigeons on 
Venice's St. Mark's Square was seen as evidence of an earlier Slavic influence. And this lead Czech writers to such pseudo-etymologies that related the Czech word holub to the Slavic stem -ljub- (love-), as is done by Jan Kollár in a special study which connects ljub(love) to the dove (holub), e.g. holub >holjub, holub>spoljub (mutual love) (Kollár 1862: 329-348 in Macura 1995: 90.)

Among the plants, it is the linden tree (lipa) that became an important symbol for Slavdom, and especially for Czechness, as it is to this day, creating such expressions as ceská lípa (the Czech linden tree). (Fig. 4-5). The Czech feminine gender for the linden tree (lipa) are bonded to many of the attributes ascribed to the dove (gentleness, sweetness, peace). In Czech Revivalist literature the linden tree is often opposed to the oak with its Czech masculine gender $(d u b)$, signifying Germanness, not only in Czech but also in German mythology (die deutsche Eiche, Er ist deutsch wie eine Eiche/the German oak, he is German as an oak). In Kollár's epic poem Slávy dcera (Sláva's Daughter) (Kollár 1832) ${ }^{5}$, and even earlier, at the beginning of the nineteenth century. Macura quotes the Czech writer Václav Stach as writing as early as 1805 (1805: 15) "The oak is a shade giver and ornament of the German fortune teller (věstec). Cannot then the linden tree be that of the Czech soothsayer? (Macura 1995: 91). Here we can see an early example of Jakobson's semantization of grammatical morphology in his example from Heine's poem "Der Fichtenbaum und die Palme" [The Fir Tree and the Palm Tree] which he cites in his "The Grammar of Poetry and the Poetry of Grammar" (Jakobson: 1981). As Jakobson notes, Heine here suggests an erotic relation between the two trees the grammatically masculine fir tree (Der Fichtenbaum) and the grammatically feminine palm tree (die Palme) interact erotically. To strengthen this idea, Heine chose to name the fir tree not by its common German name, die Fichte, which is feminine, but chose the combination with the masculine -baum which makes the entire compound noun masculine. The same grammatical semantization is cited by Jakobson in his discussion of the Russian bylina about "Vasilij and Sofija," in which a cypress (R. Masculine noun kiparis) and the willow tree (R. Fem. verba) grow out of Sofija's and Vasilij's graves respectively, and "wove together with their heads? And stuck

\footnotetext{
As Měšt'an points out (1984: 69), Kollár uses a conscious "Revivalist" etymology. The noun sláva, in Czech and Slovak, as well as in other Slavic languages, has the meaning of glory. And for Kollár and other writers of the National Revival, the etymology of the word for Slav (Slovan) is derived from this Slavic root for glory, fame.
} 
together with their leaves." (Jakobson 1981: 92). Macura notes (1995: 91) that this semantization still exists in some rural areas of Bohemia and Moravia where an oak is planted at the birth of a boy, and a linden tree at the birth of a girl. Furthering the thesis of feminine ideal for Czechness, Macura notes the frequency of the figure of the Czech amazon fighting for freedom in the 1848 revolution, a theme which became a favorite of illustrators in the Czech press, frequently with striking similarity to Delacroix's famous amazone picture. (Fig. 6-7).

The opposition linden tree / oak tree for Czechness or Slavdom in general vs. Germanness is accompanied by secondary semantizations that also model the same dichotomy of Czech vs. German. For the Czech/Slavic side, they are honey (sweetness), the bee (as the producer of sweetness with a secondary semantization of industriousness (Cz: píle, also of feminine gender)) on the Slavic side, and the bitter acorn and aggressive boar on the German side. Macura develops the following model of the Czech-German opposition (1995: 92):

Slavic (Czech)

the linden tree (lípa, fem.) Female vs. Male principle softness vs. hardness Peace loving vs. Aggressive

honey

bee (včela, f., píle, f.) sweetness vs. bitterness

Industrious vs. Aggressive

\section{German}

oak $(d u b$, masc. $)$

acorn

boar (kanec, m.)

\section{Czech "dreams" of the Revival period}

In his last book, The Czech Dream (Český sen) (1998), Macura returns again to his pivotal topic of the Czech National Revival, which he semioticizes by another opposition, that of sleep-dream (sen) vs. awakening (probuzení, buditel ${ }^{6}$ ). Here Macura analyzes fifteen Czech myths (he calls them "dreams about..."), and in the Introduction and Conclusion, he provides a meta-analysis of the Czech Revival Movement, often shown as characterized by the artificiality of a dream. In the Introduction, he demonstrates how the "Czech Dream" of nationhood in the National Revival extends into the "dreamings' of the Interwar first Czech Republic under Masaryk, and how this "dream" is

\footnotetext{
6 The leaders in the National Revival movement were also called buditele [Awakeners]
} 


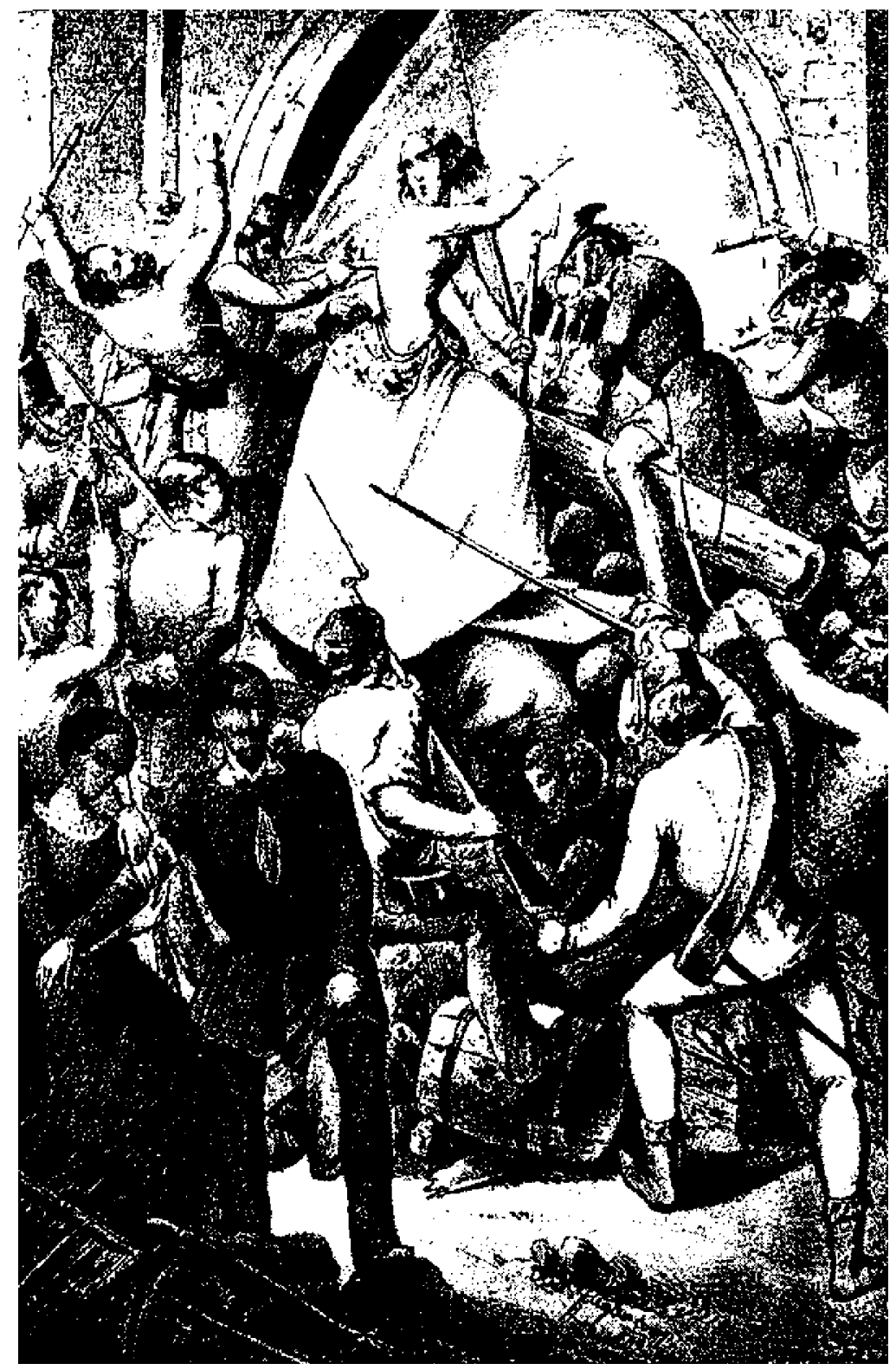

Figure 6. Amazone on the barricades under the Charles Bridge Tower on the Old Town side in Prague. From a leaflet of 1948. 


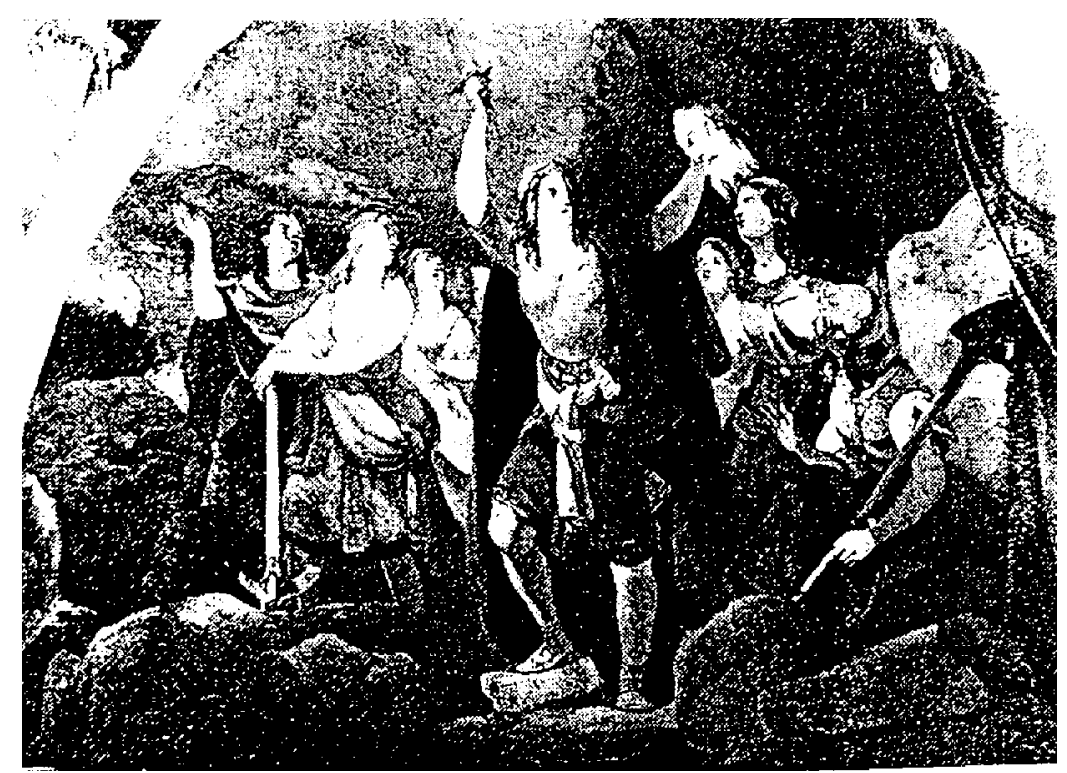

Figure 7. The mythical Czech amazone, Vlasta. Painting by Josef Navrátil.

shifted into a new semiotic model after the communist putsch of 1948 . As we have seen, the "dreaming" of the time of the Awakening was a sign of a transition towards a Czech national identity defined in contrast to German culture; Macura's analogy is the "dreaming" after the communist putsch of 1948 of the communist ideology, which is always presented as a transition to the ideal society of communism. This new "dreaming" revalued the anti-Germanism of the National Revival into the image of the hostile imperialist war-mongering West, while the Slavophilism of the Awakening was transformed into Russophilism or Sovietophilism (Macura 1998: 11-12).

Today the Czechs are again striving for a national identity, and the "bridge" is replaced by a desire for becoming part of the European Union on Czech independent terms. And Estonia also shares this new dream. In both cases, then, the search for a national identity is cast in quite new terms.

Macura, like a poet, has the ability to treat metaphorically relationship that are not always noted so clearly, and then they become a semiotic documentation of Czech culture since the Habsburg monarchy to our days. 


\section{References}

Bogatyrev, Petr 1936,1971. The Functions of Folk Costume in Moravian Slovakia. The Hague: Mouton.

Frazer, George 1925. The Golden Bought. A Study in Magic and Religion. London: Macmillan.

Gelehrte estnische Gesellschaft 1846. Verhandlungen. Dorpat (Tartu). Vols. I-III.

Herkel, Jan 1826. Elementa universalis linguae slavicae. Praha.

Jakobson, Roman with Jurij Tynjanov 1928. Problemy izucenija literatury i jazyka. Novyj LEF. Moscow.

- 1981. The poetry of grammar and the grammar of poetry. Selected Writings III: 87-97.

Janoušek, Pavel 1999. Ten, který byl... Vladimír Macura. 7.11.194517.4.1999. Česká literatura 3199: 333-136.

Jungman, Josef 1948. Boj o obrození národa [The Struggle for the Reawakening of the Nation]. Ed. Felix Vodicka. Praha.

Kollár, Jan 1832. Slávy dcera. Lyricko-epická báseň v pěti zpěvech. [Sláva's Daughter. A Lyrical-Epic Poem in Five Cantos]. Pest.j

- 1862. Cestopis obsahujicí cestu do Horní Italie a odtud pres Tyrolsko a Bavorsko se zvláštním ohledem na slavjanské żivly roku 1841 konanou. Se slovniken slavjanských umĕlciov vsech kmeniiv. [A Travel Description of a Trip to Upper Italy and from There By Way of the Tyrol and Bavaria With special Emphasis on Slavic Elements, Undertaken in the Year 1841. With a Dictionary of the Names of Slavic Artists of All Tribes]. Praha.

- 1952. Básně. Vybrané spisy I. Praha.

Lotman, Jurij M. 1990. Universe of the Mind. A Semiotic Theory of Culture. Bloomington: University of Indiana Press.

Mácha, Karel Hyněk 1961. Próza. Spisy II. (Ed. K. Janský et al). Praha.

Macura, Vladimír 1993. Masarykovy boty a jiné semi(o)fejetony. (Masaryk's Boots and Other Semi(o)feulletons). Praha: Pražská imaginance sv. 272).

- 1995. Znameníi zrodu. České národní obrození jakop kulturní typ (Signs of Birth. The Czech National Revival As a Cultural Type). Nové rozšsířené vydání. Praha (H \& H). (Ist edition 1980).

- 1998. Český sen (The Czech Dream). Praha: Lidové noviny.

Měšt'an, Antonín 1984.Geschichte der tscehischen Literatur im 19. und 20. Jahrhundert. Köln: Böhlau (Bausteine zur Geschichte der Literatur bei den Slaven. Vol. 24).

Mukařovský, Jan 1934. K českému překladu Šklovského Teorie prózy. Čin VI: $123-30$.

- 1936 Estetická funkce, norma a hodnota jako sociologický fakty. Praha.

Neruda, Jan 1961. Přes Heřmanův Městec. Menši cesty. Spisy Jana Nerudy IX (ed. Aleš Haman.) Praha. 
Palacký, František 1848. Dějiny národu českého v Čechách a v Moravě dle puivodnich pramenu [History of the Czech Nation in Bohemia and Moravia according to Original Sources]. I. Praha.

Prague Linguistic Circle, Theses 1928. Thèses présentées au premier congrès des philologues slaves. Travaux du cercle linguisticque de Prague I: 529.

Stach, Václav 1805. Starý veršovec pro rozumnou kratochvíli [Old Versebook for Reasonable Entertainment]. Praha.

Vocel, Jan Erazim 1864. Učená společnost estonská v Derptu. Učená správa ll. Časopis Českého Muzea 20: 264-270.

Winner, Thomas. 1995. Prague structuralism and semiotics: Neglect and resulting fallacies. Semiotica 105(3/4): 243-275.

\section{Чешская и Тартуско-Московская семиотика: культурная семиотика Владимира Мацуры (1945-1999)}

Среди национальных научных групп деятельность Пражского лингвистического кружка была наиболее сходна с работой МосковскоТартуской школы. В данной статье исследуется работа одного из самых неутомимых современных чешских интерпретаторов лотмановской школы Владимира Мацуры, чьи труды по чешской литературе и истории представляют собой замечательный пример отзвуков лотмановской семиотики в Чешской Республике. Это особенно касается переоценки Мацурой текстов чешского национального возрождения конца 18 - начала 19 веков, особенно в книгах "Знаки рождения" (1995) и “Чешский сон" (1998). В этих работах Мацура рассматривает этот критический период чешской национальной истории как многослойный семиотический текст и в вербальной, и в визуальной сферах. Настоящая статья представляет попытку исследования такого подхода Мацуры к чешскому языку, городу Праге, к проблеме чешской национальной самоидентификации в целом и, как части более широкой категории, славянского мира. Особое внимание уделяется исследованию Мацурой ценностных функций символических животных и растений в культуре чешского Возрождения в соотношении с аксиологией чешской (славянской) культурной идентичности. Статья посвящена памяти Мацуры. 


\section{Tšehhi ja Tartu-Moskva koolkonna semiootika: Vladimír Macura (1945-1999) kultuurisemiootika}

Rahvuslike teaduskoosluste hulgast oli Praha lingvistikaringi tegevus kõige sarnasem Tartu-Moskva koolkonna suunitlusega. Artiklis vaadeldakse tänapäeva Tšehhi ühe kõige väsimatuma Lotmani koolkonna interpreteerija Vladimír Macura tegevust, kelle tööd tšehhi kirjanduse ja ajaloo alalt kujutavad endast suurepärast näidet lotmanliku semiootika mõjuväljast Tšehhi Vabariigis. Eriti puudutab see Macura-poolset tšehhi rahvusliku ärkamisaja tekstide ümberhindamist, eelkõige raamatutes "Sünnimärgid" (1995) ja "Tšehhi unenägu" (1998). Neis tekstides vaatleb Macura seda tšehhi rahvuse ajaloo kriitilist perioodi kui mitmekihilist (nii verbaalses kui visuaalses sfärris) semiootilist teksti. Artiklis lahatakse Macura semiootilist lähenemist tšehhi keelele, Praha linnale, tšehhi rahvusliku enesemääramise probleemile tervikuna ja, laiemalt, slaavi maailmale. Erilist tähelepanu pööratakse Macura uurimusele sümboolsete loomade ja taimede väärtusfunktsioonidest tšehhi ärkamisaja kultuuris, suhestatuna tšehhi (slaavi) kultuurilise identiteediga. Artikkel on pühendatud Macura mälestusele. 